\title{
PENGARUH KOMPETENSI DAN MOTIVASI TERHADAP PRODUKTIVITAS KERJA KARYAWAN PT ASTRA INTERNATIONAL DAIHATSU, TBK CIBUBUR
}

\author{
Firman Eksan 1) \\ 1) Mahasiswa Program Studi Manajemen FE UNKRIS \\ Donny Dharmawan ${ }^{2)}$ \\ 2) Dosen Program Studi Manajemen FE UNKRIS \\ Alamat: Kampus UNKRIS, Jatiwaringin Jakarta Timur \\ Email: donnydh@gmail.com
}

\begin{abstract}
The purpose of this study was to determine the effect_of competence and motivation on employee productivity of PT. Astra International Daihatsu, Tbk Cibubur. The research method uses qualitative and quantitative descriptive analysis, the analysis model used is linear regression both simply and multiple. The study population of all employees of PT. Astra International Daihatsu, Tbk Cibubur, amounting to 57 employees. The sampling technique of this study uses saturated sampling, which is the technique of determining the sample when all members of the population are sampled. Result competence and motivation have a positive and significant effect on the Employee Productivity of PT. Astra International Daihatsu, Tbk Cibubur, both partially and simultaneous.
\end{abstract}

Keywords: Competence, motivation and employee productivity

\section{PENDAHULUAN}

Sumber daya manusia memiliki peranan penting baik secara perorangan ataupun kelompok, dan sumber daya manusia merupakan salah satu penggerak utama atas kelancaran jalannya sebuah organisasi, bahkan maju mundurnya perusahaan tergantung keberadaan sumber daya manusianya Setiap perusahaan dituntut untuk dapat mengoptimalkan sumber daya manusia dan bagaimana sumber daya manusia dikelola.

Pengelolaan sumber daya manusia tidak lepas dari faktor karyawan yang diharapkan dapat bekerja sebaik mungkin demi mencapai tujuan perusahaan. Karyawan adalah orang yang bekerja di suatu perusahaan atau lembaga dan di gaji dengan uang. Atau karyawan dapat diartikan juga sebagai orang yang bertugas sebagai pekerja pada suatu perusahaan atau lembaga untuk melakukan operasional tempat kerjanya dengan balas jasa berupa uang. Sedarmayanti (2017), menyatakan bahwa "kinerja merupakan terjemahan dari kata performance yang memiliki arti sebagai sebuah hasil kerja seorang pegawai atau pekerja, sebuah proses manajemen yang mana hasil kerja tersebut harus memiliki sebuah bukti konkret yang juga dapat diukur". Perusahaan akan dapat berjalan dan berfungsi sebagaimana mestinya jika sumber daya manusia memfungsikan sumber daya yang lainnya. Kinerja dapat dilihat seberapa besar produktivitas kerja karyawan yang dihasilkan dalam menjalankan pekerjaannya berdasarkan akal yang dimiliki, perasaan, keinginan, kemampuan, keterampilan, pengetahuan, dorongan, daya, dan karya. Semua potensi sumber daya manusia tersebut sangat berpengaruh terhadap upaya suatu organisasi dalam pencapaian tujuannya. Sumber daya manusia merupakan sumber daya yang paling dominan bila dibandingkan dengan sumber daya yang lainnya. 
Sebagaimana kita ketahui, bahwa sumber daya manusia, modal dan teknologi merupakan faktor-faktor yang sangat penting dalam menciptakan produktivitas kerja karyawan demi kemajuan perusahaan. Produktivitas kerja adalah kemampuan karyawan dalam berproduksi dibandingkan dengan input yang digunakan, seorang karyawan dapat dikatakan produktif apabila mampu menghasilkan barang atau jasa sesuai dengan diharapkan dalam waktu yang singkat atau tepat. Hasibuan (2013), menyampaikan produktivitas adalah "perbandingan antara output (hasil) dengan input (masukan). Jika Produktivitas naik ini hanya dimungkinkan oleh adanya peningkatan efisiensi (waktubahan-tenaga) dan sisitem kerja, teknik produksi dan adanya peningkatan keterampilan dari tenaga kerjanya". Untuk mencapai hal tersebut diperlukan adanya usaha yang didukung oleh semua pihak secara organisasi baik dari pihak manajemen maupun dari pihak karyawan. Pihak manajemen dalam hal ini, perlu melakukan terobosan-terobosan baru untuk menggerakan sumber daya manusia yang dimiliki tersebut.

Setiap perusahaan dibentuk untuk mencapai tujuan tertentu, dan apabila tercapai barulah dapat dikatakan berhasil. Untuk mencapai keberhasilan, diperlukan landasan yang kuat berupa kompetensi. Dengan demikian, kompetensi menjadi sangat berguna untuk membantu organisasi meningkatkan kinerjanya. Kompetensi sangat diperlukan dalam setiap proses sumber daya manusia. Semakin banyak kompetensi dipertimbangkan, maka semakin meningkat pula kinerjanya. Robbins (2008), mengemukakan kompetensi adalah "suatu kemampuan atau kapasitas seseorang untuk melakukan berbagai tugas dalam suatu pekerjaan, dimana kemampuan tersebut ditentukan oleh faktor intelektual dan fisik". Kompetensi dapat memperdalam dan memperluas kemampuan kerja. Semakin sering seseorang melakukan pekerjaan yang sama, semakin terampil dan semakin cepat pula dia menyelesaikan pekerjaan tersebut. Semakin banyak macam pekerjaan yang dilakukan seseorang, pengalaman kerjanya semakin kaya dan luas, dan memungkinkan peningkatan kinerjanya (Simanjuntak, 2011).

Selain kompetensi, motivasi juga merupakan salah satu faktor yang harus diperhatikan sepenuhnya oleh perusahaan, karena motivasi juga merupakan faktor yang dominan dalam usaha meningkatkan produktiviyas kerja karyawan. Flippo (dalam Hasibuan 2013), menyebutkan bahwa motivasi adalah "suatu keahlian, dalam mengarahkan pegawai dan organisasi agar mau bekerja secara berhasil, sehingga para pegawai dan tujuan organisasi sekaligus tercapai". Motivasi sangat penting bagi perusahaan karena dengan adanya motivasi diharapkan setiap orang mau bekerja keras dan antusias untuk mencapai produktivitas kerja yang tinggi guna mempertahankan usaha. Dengan kata lain, motivasi adalah proses manajemen untuk mempengaruhi tingkah laku manusia untuk mencapai tujuan tertentu.

PT. Astra International - Daihatsu Sales Operation (AI - DSO) yang berdiri sejak tahun 1973 adalah sebuah perusahaan otomotif terbesar yang bergerak di bidang distribusi, penjualan, dan after sales service Daihatsu yang manajemennya ditangani penuh oleh PT. Astra International. Daihatsu Sales Operation (DSO) adalah distributor tunggal sekaligus retailer kendaraan merk Daihatsu yang kendaraannya didistribusikan oleh Astra melalui Divisi DSO yang memiliki 137 jaringan penjualan di seluruh Indonesia, dimana 71 outlet penjualan merupakan cabang langsung dari Astra dan salah satunya adalah AI - DSO cabang Cibubur yang terletak di Jalan Raya Trans Yogie, no. 68, Jakarta Timur.

AI - DSO cabang Cibubur memiliki tiga divisi, yaitu divisi sales yang melayani penjualan kendaraan baru dengan merk Daihatsu, divisi administrasi yang menangani keseluruhan administrasi perusahaan, dan yang terakhir adalah divisi service yang menjalankan pelayanan purna jual berupa perbaikan, perawatan, dan penyediaan suku cadang asli Daihatsu. 
Terdapat tiga indikator parameter keberhasilan bengkel, yaitu booking rate, unit entry, dan revenue. Perolehan revenue sendiri didapatkan dari hasil penjualan saat pelanggan melakukan service, seperti penjualan jasa, bahan, dan spare part. Kebutuhan spare part biasanya terjadi bukan karena kebutuhan service semata, namun juga karena adanya pekerjaan tambahan yang ditemukan pada saat kendaraan pelanggan diperbaiki di bengkel.

Dalam melakukan pekerjaan masih terlihat adanya beberapa karyawan sering melimpahkan tugas atau pekerjaanya kepada karyawan lain yang lebih memiliki keterampilan sehingga butuh waktu lama untuk menyelesaikan tugas tersebut. Kondisi ini berdampak pada lebih lamanya waktu pelanggan untuk menunggu penyelesaian service kendaraan. Selain itu, karyawan kurang cepat atau sigap dalam bekerja karena selalu menunggu perintah atasan. Karyawan juga hanya memfokuskan informasi dari service advisor dalam mengambil tugasnya, tidak ada inisiatif sendiri untuk terlebih dahulu mengambil apa yang menjadi tugasnya. Kurangnya kemampuan dan keterampilan karyawan ini mengindikasikan bahwa kompetensi yang dimiliki karyawan belum sesuai dengan target yang diinginkan perusahaan. Hal inilah yang menjadi salah satu faktor belum tercapainya produktivias kerja karyawan secara optimal.

Selain kompetensi, faktor lain yang diduga menyebabkan menurunnya kinerja karyawan yaitu kurangnya motivasi yang diberikan perusahaan terhadap karyawan. Kondisi ini terlihat dari kurangnya kesempatan karyawan dalam mengasah kemampuan atau keterampilan untuk dapat mengembangkan karir mereka. Dan juga adanya ketidaknyamanan yang dirasakan karyawan di dalam lingkungan perusahaan. Masih banyak hal yang harus dilakukan perusahaan agar dapat memotivasi karyawan. Salah satunya adalah memberikan kesempatan pada karyawan untuk dapat mengembangkan kemampuan dan keterampilan dan juga memberikan kesempatan untuk dapat mengembangkan karir mereka.

Tujuan dari penelitian ini adalah untuk mengetahui "pengaruh kompetensi dan motivasi terhadap produktivitas kerja karyawan PT Astra International Daihatsu, Tbk Cibubur".

\section{LANDASAN TEORI}

\section{Produktivitas Kerja}

Pada dasarnya produktivitas kerja dapat diartikan suatu sikap yang mencakup mental dan selalu mempunyai pandangan bahwa kehidupan dihari ini lebih baik dari hari kemarin dan kehidupan dihari esok harus lebih baik dari hari ini.

Hasibuan (2013), menyatakan produktivitas adalah "perbandingan antara output (hasil) dengan input (masukan). Jika Produktivitas naik ini hanya dimungkinkan oleh adanya peningkatan efisiensi (waktu-bahan-tenaga) dan sisitem kerja, teknik produksi dan adanya peningkatan keterampilan dari tenaga kerjanya". Sinungan, (2011), secara umum produktivitas diartikan "sebagai hubungan antara hasil nyata maupun fisik (barang-barang atau jasa) dengan masuknya yang sebenarnya. Produktivitas juga diartikan sebagai tingkatan efisiensi dalam memproduksi barang-barang atau jasa - jasa. Produktivitas juga diartikan sebagai: (a) Perbandingan ukuran harga bagi masukan dan hasil. (b) Perbedaan antara kumpulan jumlah pengeluaran dan masukan yang dinyatakan dalam satuan-satuan (unit) umum". Pengertian Produktivitas menurut Handoko (2012), Produktivitas adalah "hubungan antara masukan-masukan dan keluaran-keluaran suatu sistem produktif. Dalam teori, sering mudah untuk mengukur hubungan ini sebagai rasio keluaran dibagi masukan. Bila lebih banyak keluaran diproduksi dengan jumlah masukan sama, produktivitas naik. 
Begitu juga, bila lebih sedikit masukan digunakan untuk sejumlah keluaran sama, produktivitas juga naik".

Berdasarkan pendapat para ahli, maka dapat disimpulkan bahwa produktivitas kerja adalah kemampuan seoarang karyawan atau staf dalam suatu perusahaan dalam berproduksi dibandingkan dengan input yang digunakan, seorang karyawan dalam suatu perusahaan atau instansi dapat dikatakan produktif jika mampu menghasilkan produk dengan jangka waktu yang singkat dan sesuai dengan tujuan yang diharapkan perusahaan.

Faktor-faktor yang mempengaruhi produktivitas kerja antara lain: 1). Bersumber dari pekerjaan; Suatu pekerjaan yang banyak memerlukan gerakan yang dapat mengakibatkan produktivitas kerja menjadi rendah. Oleh karena itu, agar gerakan dalam melakukan pekerjaan cepat dan tepat terlebih dahulu diadakan "Time and Motion Study". Dengan dua studi tersebut dapat tercipta gerakan-gerakan yang efektif dan dapat memperlancar pekerjaan sekaligus mengurangi kesalahan karyawan. 2). Bersumber dari karyawan itu sendiri; Semangat dan kegairahan kerja para karyawan merupakan unsur penting guna mencapai produktivitas yang tinggi. Maka sebaiknya pimpinan memperhatikan unsur penting tersebut seperti melalui: a). Gaji yang memadai; b). Kebutuhan karyawan perlu diperhatikan; c). Penempatan karyawan pada posisi yang tepat.

Selain dari kedua sumber tersebut diatas maka faktor-faktor lain yang mempengaruhi produktivitas kerja adalah: 1). Pendidikan; Tingkat kecerdasan karyawan dilihat dari tingkat pendidikannya. Semakin tinggi pendidikan semakin besar kemungkinan untuk mendapatkan tujuan kejenjang yang lebih baik. Oleh karena itu, pendidikan berhubungan dengan produktivitas kerja staf dan karyawan. 2). Kesehatan jasmani dan rohani; Salah satu tugas pimpinan perusahaan adalah menjamin kesehatan karyawan yaitu dengan cara mengatur jam kerja, meniadakan lembur sehingga dapat menciptakan kegiatan kerja para karyawan. Karyawan yang sehat juga pasti akan dapat meningkatkan produktivitas kerjanya. 3). Lingkungan kerja; Lingkungan kerja yang baik akan berpengaruh besar dalam meningkatkan produktivitas. Lingkungan kerja yang bersih dapat mempengaruhi karyawan untuk bekerja lebih giat. 4). Faktor Manajerial; Gaya kepemimpinan yang efektif, memotivasi, mengarahkan, dan menggerakan bawahannya agar dapat bekerja dengan lebih semangat dan bergairah dalam melaksanakan tugas. 5). Motivasi; Pemberian motivasi oleh seseorang pimpinan yang baik akan membimbing dan melatih karyawannya. Memotivasi setiap karyawan tidaklah mudah, sebab setiap karyawan mempunyai latar belakang, pengalaman, harapan dan keinginan yang berbeda. 6). Peralatan yang digunakan; Peralatan yang digunakan mempunyai efek yang sangat penting dalam meningkatkan produktivitas kerja. Produktivitas kerja seorang karyawan perlu mendapat perhatian dari perusahan karena produktivitas kerja akan meningkatkan keuntungan bagi perusahaan. Produktivitas dapat dimaksudkan sebagai penggunaan sumber-sumber ekonomi yang digerakan secara efektif dan memerlukan keterangan organisator dan teknik sehingga mempunyai tingkat hasil guna yang tinggi, artinya hasil yang diperoleh seimbang dengan masukan yang diolah.

Adapun hal-hal yang dinilai atas diri karyawan adalah hal-hal yang dapat mendorong produktivitas atau prestasi kerja setiap karyawan seperti kesetiaan atau loyalitas karyawan, kejujuran, kepemimpinan, kerja sama, dedikasi dan partisipasi karyawan didalam perusahaan atau instansi.

Produktivitas kerja karyawan memiliki pengaruh pada tujuan yang ingin dicapai oleh perusahaan. Maka dari itu setiap perusahaan harus melakukan pengukuran pada produktivitas kerja karyawan. Menurut Dharma (2010) untuk dapat mengevaluasi para karyawan secara objektif dan akurat kita harus mampu mengukur tingkat produktivitas kerja mereka. Tentang pengukuran produktivitas kerja, Dharma (2010) berpendapat bahwa 
cara pengukuran produktivitas kerja perlu mempertimbangkan hal-hal sebagai berikut: 1). "Kuantitas, yaitu jumlah yang harus diselesaikan; Pengukuran kuantitatif melibatkan perhitungan dari proses atau pelaksanaan kegiatan. Hal ini berkaitan dengan jumlah keluaran (output) yang dihasilkan. 2). Kualitas, yaitu mutu yang dihasilkan; Pengukuran kualitatif keluaran (output) menceriminkan "tingkat kepuasan", yaitu seberapa baik penyelesaian dari suatu pekerjaan. c). Ketepatan waktu, yaitu sesuai tidaknya dengan waktu yang telah direncanakan; Pengukuran ketepatan waktu merupakan jenis khusus dari pengukuran kuantitatif yang menentukan ketepatan waktu penyelesaian suatu kegiatan".

Produktivitas kerja sebagai suatu konsep yang menunjukkan adanya kaitan antara hasil kerja dengan satuan waktu yang dibutuhkan untuk menghasilkan produk tertentu dari seorang tenaga kerja. Pengukuran produktivitas kerja pada dasarnya digunakan untuk mengetahui sejauh mana tingkat efektifitas dan efisiensi kerja karyawan dalam menghasilkan suatu hasil. Dalam usaha untuk dapat mengukur tingkat kemampuan karyawan dalam mencapai sesuatu hasil yang lebih baik dan ketentuan yang berlaku (kesuksesan kerja).

Tingkat produktivitas kerja yang dapat diukur menurut (Damayanti, 2005) adalah: 1). "Penggunaan waktu; Penggunaan waktu kerja sebagai alat ukur produktivitas kerja karyawan melalui: a). Kecepatan waktu kerja; b). Penghematan waktu kerja; c). Kedisiplinan waktu kerja; d). Tingkat absesnsi. 2). Output yaitu hasil produksi karyawan yang diperoleh sesuai produk yang diinginkan perusahaan”.

Sutrisno, (2011), menyatakan produktivitas merupakan hal yang sangat penting bagi para karyawan yang ada di perusahaan. Dengan adanya produktivitas kerja diharapkan pekerjaan akan terlaksana secara efesien dan efektif. Sehingga ini semua sangat diperlukan dalam pencapain tujuan yang sudah ditetapkan untuk mengukur produktivitas kerja diperlukan suatu indikator, sebagai berikut: 1). "Kemampuan; Mempunyai kemampuan untuk melaksanakan tugas. Kemampuan seorang karyawan sangat bergantung pada keterampilan yang dimiliki serta profesionalisme mereka dalam bekerja. Ini memberikan daya untuk menyelesaikan tugas-tugas yang diembannya kepada mereka. 2). Meningkatkan hasil yang dicapai; Berusaha untuk meningkatkan hasil yang dicapai. Hasil merupakan salah satu yang dapat dirasakan baik oleh yang mengerjakan maupun yang menikmati hasil pekerjaan tersebut. jadi, upaya untuk memanfaatkan produktivitas kerja bagi masing-masing yang terlibat dalam suatu pekerjaan. 3). Semangat kerja; Ini merupakan usaha untuk lebih baik dari hari kemarin. Indikator ini dapat dilihat dari etos kerja dan hasil yang dicapai dalam suatu hari kemudian dibandingkan dengan hari sebelumnya. 4). Pengembangan diri; Senantiasa mengembangkan diri untuk meningkatkan kemampuan kerja. Pengembangan diri dapat dilakukan dengan melihat tantangan dan harapan dengan apa yang akan dihadapi. Sebab semakin kuat tantangannya, pengembangan diri mutlak dilakukan. Begitu juga harapan untuk menjadi lebih baik pada gilirannya akan sangat berdampak pada keinginan karyawan untuk meningkatkan kemampuan. 5). Mutu; Selalu berusaha untuk meningkatkan mutu lebih baik dari yang telah lalu. Mutu merupakan hasil pekerjaan yang dapat menunjukkan kualitas kerja seorang pegawai. Jadi, meningkatkan mutu bertujuan untuk memberikan hasil yang baik yang pada gilirannya akan sangat berguna bagi perusahaan dan dirinya sendiri. 6). Efisiensi; Perbandingan antara hasil yang dicapai dengan keseluruhan sumber daya yang digunakan. Masukan dan keluaran merupakan aspek produktivitas yang memberikan pengaruh yang cukup signifikan bagi karyawan".

\section{Kompetensi}


Kompetensi adalah suatu kemampuan atau kecakapan yang dimiliki oleh seseorang dalam melaksanakan suatu pekerjaan atau tugas di bidang tertentu, sesuai dengan jabatan yang disandangnya. Robbins (2008), menyampaikan pengertian kompetensi adalah "suatu kemampuan atau kapasitas seseorang untuk melakukan berbagai tugas dalam suatu pekerjaan, dimana kemampuan tersebut ditentukan oleh faktor intelektual dan fisik". Sedarmayanti (2017), pengertian kompetensi adalah "suatu karakteristik yang mendasari seseorang dan berhubungan dengan efektivitas kinerja individu dalam melakukan pekerjaannya". Mangkunegara (2015), pengertian kompetensi adalah "suatu faktor mendasar yang ada pada seseorang yang memiliki kemampuan lebih dan membuatnya berbeda dengan orang lain dengan kemampuan rata-rata”. Menurut UU No. 13 Tahun 2003 Tentang Ketenagakerjaan, kompetensi kerja adalah "kemampuan kerja setiap individu yang mencakup aspek pengetahuan, keterampilan, dan sikap kerja yang sesuai dengan standar yang ditetapkan".

Menurut Ruky (dalam Sutrisno 2011), perusahaan-perusahaan besar menggunakan kompetensi sebagai dasar dalam merekrut tenaga kerja. Adapun beberapa manfaat merekrut pekerja yang memiliki kompetensi adalah sebagai berikut: 1). "Memperjelas standar kerja dan harapan yang ingin dicapai oleh perusahaan. 2). Kompetensi individu dapat digunakan sebagai alat seleksi tenaga kerja yang potensial. 3). Kecakapan tenaga kerja akan memaksimalkan produktivitas perusahaan. 4). Kecakapan atau kompetensi tenaga kerja dapat dijadikan dasar dalam mengembangkan sistem remunerasi. 5). Kompentensi dapat membantu perusahaan untuk dapat beradaptasi terhadap perubahaan yang terjadi. 6). Kompetensi dapat memudahkan perusahaan dalam menyelaraskan perilaku kerja dengan nilai-nilai organisasi”.

Menuruw Zwell (2010) terdapat beberapa faktor yang bisa mempengaruhi kompetensi seseorang. Faktor-faktor tersebut diantaranya adalah: 1). "Keyakinan dan nilainilai; 2). Keterampilan; 3). Pengalaman; 4). Karakteristik pribadi; 5). Motivasi; 6). Isu emosional; 7). Kemampuan intelektual".

Indikator kompetensi kerja menurut Wibowo (2011), yaitu: 1). "Pengetahuan adalah pengetahuan yang dimilki oleh seorang karyawan untuk melaksanakan tugas dan tanggung jawab sesuai dengan bidang atau divisi yang dikerjakannya. 2). Keterampilan adalah kemampuan yang harus dimiliki oleh setiap karyawan untuk melaksanakan suatu tugas dan tanggung jawab yang diberikan oleh perusahaan secara maksimal. 3). Perilaku adalah pola tingkah laku karyawan dalam melaksanakan tugas dan tanggung jawabnya sesuai dengan peraturan perusahaan".

\section{Motivasi}

Manajer atau pemimpin adalah orang-orang yang mencapai hasil melalui orang lain, yaitu para bawahan. Oleh karena itu, sudah menjadi kewajiban dari setiap pemimpin agar para bawahannya berprestasi. Prestasi bawahan, terutama disebabkan oleh dua hal, yaitu kemampuan dan daya dorong. Kemampuan seorang ditentukan oleh kualifikasi yang dimilikinya antara lain oleh pendidikan, pengalaman dan sifat-sifat pribadi, sedangkan daya dorong dipengaruhi oleh suatu yang ada dalam diri seseorang dan hal-hal lain di luar dirinya.

Robbins, et, al. (dalam Winardi 2007), merumuskan "motivasi sebagai kesediaan untuk melaksanakan upaya tinggi untuk mencapai tujuan-tujuan keorganisasian yang dikondisikan oleh kemampuan upaya untuk memenuhi kebutuhan individual tertentu". Adair (2007), mengemukakan motivasi adalah "apa yang membuat orang melakukan sesuatu, tetapi arti yang lebih penting dari kata ini adalah bahwa motivasi adalah apa yang membuat orang benar-benar berusaha dan mengeluarkan energi demi apa yang mereka 
lakukan". Definisi yang sederhana dari kata 'motivasi' mungkin "membuat orang mengerjakan apa yang harus dikerjakan dengan rela dan baik". Mangkunegara (2015), menyatakan "motivasi terbentuk dari sikap (attitude) karyawan dalam menghadapi situasi kerja di perusahaan (situation). Motivasi merupakan kondisi atau energi yang menggerakkan diri karyawan yang terarah atau tertuju untuk mencapai tujuan organisasi perusahaan. Sikap mental karyawan yang pro dan positif terhadap situasi kerja itulah yang memperkuat motivasi kerjanya untuk mencapai kinerja maksimal".

Pimpinan perusahaan adalah sosok yang sangat berpengaruh pada peningkatan motivasi karyawan. Teori motivasi harus dipahami oleh pimpinan, sehingga mampu mengidentifikasi apa yang memotivasi karyawan bekerja, hubungan perilaku kerja dengan motivasi dan mengapa karyawan berprestasi tinggi.

Ada beberapa teori motivasi yang dikemukakan oleh ilmuwan yang menekuni kegiatan pengembangan teori motivasi. Berikut beberapa teori motivasi: 1). "Teori Abraham Maslow. Kebutuhan dapat didefinisikan sebagai suatu kesenjangan atau pertentangan yang dialami antara suatu kenyataan dengan dorongan yang ada dalam diri. Kebutuhan merupakan fundamen yang mendasari perilaku karyawan. Kita tidak akan bisa memotivasi karyawan jika kebutuhan karyawan belum bisa terpenuhi oleh perusahaan. Pemenuhan motivasi harus sesuai dengan kebutuhan yang diinginkan oleh karyawan. Maslow melihat adanya kebutuhan yang harus dipenuhi oleh karyawan. Maslow mengemukakan bahwa hirarki kebutuhan manusia adalah sebagai berikut: a). "Kebutuhan fisiologis, yaitu kebutuhan untuk makan, minum, perlindungan fisik, bernafas, seksual. Kebutuhan ini merupakan kebutuhan tingkat terendah atau disebut pula sebagai kebutuhan yang paling dasar. b). Kebutuhan akan harga diri, adalah kebutuhan untuk dihormati dan dihargai oleh orang lain. c). Kebutuhan untuk mengaktualisasikan diri, yaitu kebutuhan untuk menggunakan kemampuan, skill, dan potensi. Kebutuhan untuk berpendapat dengan mengemukakan ide-ide memberi penilaian dan kritik terhadap sesuatu”. 2). Teori Dua Faktor Herzberg. Teori ini dikembangkan oleh Frederic Hezberg, teori ini juga menggunakan teori Maslow sebagai titik acuannya. Hezberg melakukan penelitian dengan cara melakukan wawancara. Masing-masing responden diminta untuk menceritakan sesuatu yang terjadi entah itu yang menyenangkan (memberikan kepuasan) ataupun tidak menyenangkan.atau yang tidak memberikan kepuasan. Kemudian hasil wawancara itu dianalisis dengan menggunakan analisis isi untuk menentukan mana faktor yang memberikan kepuasan atau yang tidak memberikan kepuasan. 3). Teori Motivasi Berprestasi McClelland. McClelland, mengemukakan bahwa produktivitas seseorang sangat ditentukan oleh "virus mental" yang ada pada dirinya. Virus mental adalah kondisi jiwa yang mendorong seseorang yang mampu mencapai prestasinya secara maksimal. Virus mental yang dimaksud terdiri dari 3 dorongan kemampuan, yaitu: a). Need of achievement (kebutuhan untuk berprestasi), b). Need of affiliation (kebutuhan untuk memperluas pergaulan), c). Need of power (kebutuhan untuk menguasai sesuatu). Berdasarkan teori McClelland tersebut sangat penting dibinanya virus mental manajer dengan cara mengembangkan potensi mereka melalui lingkungan kerja secara efektif agar terwujudnya produktifitas perusahaan yang berkualitas tinggi dan tercapainya tujuan utama organisasi".

Motivasi sebagai proses batin atau proses psikologis dalam diri seseorang, sangat dipengaruhi oleh beberapa faktor antara lain: 1). "Faktor Ekstern; a). Lingkungan kerja; b). Pemimpin dan kepemimpinannya; c). Tuntutan perkembangan organisasi atau tugas; d). Dorongan atau bimbingan atasan. 2). Faktor Intern; a). Pembawaan individu; b). Tingkat pendidikan; c). Pengalaman masa lampau; d). Keinginan atau harapan masa depan". 
Perusahaan selalu berusaha memanfaatkan seluruh sumber daya yang dimilikinya secara optimal dan sebaik mungkin. Hal ini terjadi karena saat ini perusahaan berusaha bertahan dengan cara meminimalkan pengeluaran dan mengoptimalkan pendapatan, karena perekonomian saat ini masih belum stabil. Sumber daya manusia merupakan salah satu faktor yang terpenting dalam menentukan keberhasilan sebuah perusahaan. Dalam usaha memanfaatkan sumber daya manusia agar dapat optimal, perusahaan perlu mendorong karyawan untuk bekerja lebih giat dan memberikan dorongan agar prestasi kerja dapat meningkat sesuai dengan harapan perusahaan. Pelaksanaan motivasi kepada seluruh karyawan merupakan salah satu faktor yang mempengaruhi prestasi kerja karyawan. Motivasi atau dorongan yang dilakukan oleh perusahaan mempunyai maksud untuk meningkatkan prestasi kerja karyawan agar lebih semangat, efektif dan efisien.

Menurut Maslow yang dikutip oleh Hasibuan (2013), bahwa motivasi kerja karyawan dipengaruhi oleh banyak kebutuhan, kemudian dari faktor kebutuhan tersebut diturunkan menjadi indikator-indikator untuk mengetahui tingkat motivasi pada karyawan, yaitu: 1). "Kebutuhan fisik, ditunjukan dengan: pemberian gaji, pemberian bonus, uang makan, uang transport, fasilitas perumahan, dan sebagainya. 2). Kebutuhan rasa aman dan keselamatan, ditunjukan dengan: fasilitas keamanan dan keselamatan kerja yang diantaranya seperti adanya jaminan sosial tenaga kerja, dana pensiun, tunjangan kesehatan, asuransi kecelakaan, dan perlengkapan keselamatan kerja. Kebutuhan sosial, ditunjukan dengan: melakukan interaksi dengan orang lain yang diantaranya untuk diterima dalam kelompok dan kebutuhan untuk mencintai dan dicintai. 3). Kebutuhan akan penghargaan, ditunjukan dengan: pengakuan dan penghargaan berdasakan kemampuannya, yaitu kebutuhan untuk dihormati dan dihargai oleh karyawan lain dan pimpinan terhadap prestasi kerja. 4). Kebutuhan perwujudan diri, ditunjukan dengan sifat pekerjaan yang menarik dan menantang, dimana karyawan tersebut akan mengerahkan kecakapan, kemampuan, keterampilan, dan potensinya. Dalam pemenuhan kebutuhan ini dapat dilakukan oleh perusahaan dengan menyelenggarakan pendidikan dan pelatihan".

\section{METODE PENELITIAN}

Berdasarkan jenis penelitiannya, yakni verifikatif yang dilaksanakan melalui pengumpulan data di lapangan, maka metode penelitian yang akan digunakan adalah metode explanatory survey. Data yang digunakan adalah data primer dan untuk mengukur besarnya pengaruh kompetensi dan motivasi terhadap produktivitas kerja karyawan PT Astra Internasional Daihatsu, Tbk Cibubur menggunakan teknik analisis regresi berganda dan sederhana dengan populasi karyawan PT Astra Internasional Daihatsu, Tbk Cibubur yang berjumlah 57 orang, dengan teknik pengambilan sampel dalam penelitian ini menggunakan teknik sampling jenuh (sensus), yaitu teknik pengumpulan sampel bila semua anggota populasi digunakan sebagai sampel.

\section{HASIL PENELITIAN DAN PEMBAHASAN}

\section{Hasil Penelitian \\ Uji Instrumen Data}

Berdasarkan uraian tersebut di atas, maka untuk dapat menentukan apakah variabel kompetensi dan motivasi dapat dijadikan pengukur terhadap produktivitas kerja karyawan PT Astra Internasional Daihatsu, Tbk Cibubur. Namun sebelumnya data diolah terlebih dahulu dan dilakukan pengujian terhadap varibel yang digunakan yaitu kompetensi dan motivasi untuk mengetahui apakah data tersebut akurat dan dapat dipercaya. 


\section{Uji Validitas}

Pengujian validitas ini dilakukan untuk menguji apakah tiap butir pernyataan telah mewakili indikator yang akan diteliti, persyaratan minimum untuk dapat dikatakan valid adalah $\mathrm{r}=0,30$. Jadi, apabila korelasi antara butir-butir item pernyataan dengan skor total kurang dari 0,30, maka butiran dalam instrumen tersebut dapat dikatakan tidak valid. Uji validitas dilakukan dengan melihat korelasi antara skor masing-masing item pernyataan dengan skor total.

\section{Uji Validitas Instrumen Variabel}

Dari perhitungan koefisien korelasi skor tiap butir pernyataan instrument dari 57 responden tentang kompetensi dengan jumlah 9 pernyataan; instrumen motivasi 8 pernyataan dan instrumen produktivitas kerja 10 pernyataan dengan total skor setiap responden diperoleh bahwa dari semua butir pernyataan variabel kompetensi, motivasi dan produktivitas kerja karyawan hasilnya adalah valid.

\section{Uji Reliabilitas}

Pengujian reliabilitas ini dilakukan untuk menguji seberapa jauh hasil pengukuran yang dapat diandalkan secara konsisten. Pada tabel hasil pengujian reliabilitas berikut, diketahui bahwa semua variabel mempunyai alpha di atas 0,6 yang berarti bahwa semua variabel dalam penelitian ini dapat diandalkan.

Tabel 1: Hasil Uji Reliabilitas Variabel

\begin{tabular}{lcc}
\hline \multicolumn{1}{c}{ Variabel } & Cronbach's Alpha & Keterangan \\
\hline Kompetensi & 0.827 & Reliabel \\
Motivasi & 0.671 & Reliabel \\
Produktivitas Kerja & 0.753 & Reliabel \\
\hline
\end{tabular}

Sumber: Hasil pengolahan data, 2020

Berdasarkan angka-angka reliabilitas cronbach alpha tersebut tampak bahwa seluruh pernyataan yang ada membentuk ukuran yang reliabel kompetensi, motivasi, dan produktivitas kerja membentuk ukuran yang reliabel dari masing-masing variabel.

\section{Analisis Hasil Penelitian}

Tabel 2: Pengaruh Kompetensi Terhadap Produktivitas Kerja Karyawan PT Astra International Daihatsu, Tbk Cibubur

\begin{tabular}{lccccc}
\hline \multirow{2}{*}{ Variabel } & $\begin{array}{c}\text { R } \\
\text { Square }\end{array}$ & $\begin{array}{c}\text { Konsta } \\
\text { nta }\end{array}$ & $\begin{array}{c}\text { Koefisien } \\
\text { Regresi }\end{array}$ & Sig & $\boldsymbol{\alpha}$ \\
\hline Kompetensi & 0,799 & 10,947 & 0,783 & 0,000 & 0.05 \\
\hline Pengujian Signifikan & & & & \\
\hline t hitung $>$ t tabel $=14,795>2,004$ \\
\hline Keterangan: Variabel Produktivitas Kerja & & & \\
Sumber : data diolah 2020
\end{tabular}

Berdasarkan Tabel 2, nilai koefisien determinasi $\left(\mathrm{R}^{2}\right)$ sebesar 0.799 , artinya variabel kompetensi memberikan kontribusi sebesar 79,9\% kepada produktivitas kerja karyawan PT Astra International Daihatsu, Tbk Cibubur, sedangkan sisanya sebesar 20,1\% disumbangkan variabel lain yang tidak diteliti. 
Kompetensi berpengaruh positif dan signifikan pada tingkat nyata 99\% terhadap produktivitas kerja karyawan PT Astra International Daihatsu, Tbk Cibubur. Koefisien kompetensi sebesar 0,783, artinya jika ada peningkatan kompetensi satu kali, maka produktivitas kerja karyawan PT Astra International Daihatsu, Tbk Cibubur akan meningkat sebesar 0,783 kali atau sebaliknya. Untuk menguji hubungan secara parsial variabel kompetensi terhadap produktivitas kerja karyawan PT Astra International Daihatsu, Tbk Cibubur signifikan atau tidak, dilakukan pengujian $\mathrm{t}$ hitung dibandingkan dengan $\mathrm{t}_{\text {tabel }}$ dengan tingkat $\alpha=0,05$, hasilnya adalah $\mathrm{t}_{\text {tabel }}=2,004$ yang dilihat dari tabel distribusi $\mathrm{t}$ (derajat kebebasan $=\mathrm{n}-2 ;(57-2=55)$, dengan uji dua pihak). Berdasarkan perhitungan tersebut di atas dapat dinyatakan bahwa Nilai $t_{\text {hitung }}=14,795$ dan $t_{\text {tabel }}=2,004$ atau $\mathrm{t}_{\text {hitung }}>\mathrm{t}$ tabel $(14,795>2,004)$, maka dapat diartikan terdapat pengaruh yang positif dan signifikan variabel kompetensi terhadap produktivitas kerja karyawan PT Astra International Daihatsu, Tbk Cibubur.

Tabel 3: Pengaruh Motivasi Terhadap Produktivitas Kerja Karyawan PT Astra International Daihatsu, Tbk Cibubur

\begin{tabular}{lccccc}
\hline \multirow{2}{*}{ Variabel } & $\begin{array}{c}\text { R } \\
\text { Square }\end{array}$ & $\begin{array}{c}\text { Konst } \\
\text { anta }\end{array}$ & $\begin{array}{c}\text { Koefisien } \\
\text { Regresi }\end{array}$ & Sig & $\boldsymbol{\alpha}$ \\
\hline Motivasi & 0,612 & 8,236 & 0,997 & 0,000 & 0.05 \\
\hline Pengujian Signifikan & & & & \\
\hline t hitung $>$ t tabel $=9,306>2,004$ & & & & \\
\hline $\begin{array}{l}\text { Keterangan: Variabel Produktivitas Kerja } \\
\text { Sumber : data diolah } 2020\end{array}$
\end{tabular}

Berdasarkan Tabel 3, nilai koefisien determinasi $\left(\mathrm{R}^{2}\right)$ sebesar 0.612 , artinya variabel motivasi memberikan kontribusi sebesar $61,2 \%$ kepada variabel produktivitas kerja karyawan PT Astra International Daihatsu, Tbk Cibubur, sedangkan sisanya sebesar 38,8\% disumbangkan variabel lain yang tidak diteliti.

$$
\text { Persamaan Regresi } \mathrm{Y}=8,236+0,997\left(\mathrm{X}_{2}\right)
$$

Motivasi berpengaruh positif dan signifikan pada tingkat nyata 99\% terhadap produktivitas kerja karyawan PT Astra International Daihatsu, Tbk Cibubur. Koefisien motivasi sebesar 0,997, artinya jika ada peningkatan motivasi satu kali, maka produktivitas kerja karyawan PT Astra International Daihatsu, Tbk Cibubur akan meningkat sebesar 0,997 kali atau sebaliknya. Untuk menguji hubungan secara parsial variabel motivasi terhadap produktivitas kerja karyawan PT Astra International Daihatsu, Tbk Cibubur signifikan atau tidak, dilakukan pengujian $\mathrm{t}$ hitung dibandingkan dengan $\mathrm{t}$ tabel dengan tingkat $\alpha=0,05$, hasilnya adalah $\mathrm{t}_{\text {tabel }}=2,004$ yang dilihat dari tabel distribusi $\mathrm{t}$ (derajat kebebasan $=\mathrm{n}-2 ;(57-2=55)$, dengan uji dua pihak). Berdasarkan perhitungan tersebut di atas dapat dinyatakan bahwa Nilai $\mathrm{t}_{\text {hitung }}=9,306$ dan $\mathrm{t}_{\text {tabel }}=2,004$ atau $\mathrm{t}_{\text {hitung }}>\mathrm{t}_{\text {tabel }}(9,306>$ 2,004), maka dapat diartikan terdapat pengaruh yang positif dan signifikan variabel motivasi terhadap produktivitas kerja karyawan PT Astra International Daihatsu, Tbk Cibubur. 
Tabel 4: Pengaruh Kompetensi dan Motivasi Terhadap Produktivitas Kerja Karyawan PT Astra International Daihatsu, Tbk Cibubur

\begin{tabular}{|c|c|c|c|c|c|}
\hline \multirow[b]{2}{*}{ Variabel } & \multicolumn{5}{|c|}{ Parameter } \\
\hline & $\begin{array}{c}\mathbf{R} \\
\text { Square }\end{array}$ & Konstanta & $\begin{array}{c}\text { Koefisien } \\
\text { Regresi }\end{array}$ & Sig. & $\alpha$ \\
\hline $\begin{array}{l}\text { Kompetensi } \\
\text { Motivasi }\end{array}$ & 0,841 & 6,056 & $\begin{array}{l}0,599 \\
0,374\end{array}$ & $\begin{array}{l}0,000 \\
0,000\end{array}$ & 0,05 \\
\hline
\end{tabular}

Pengujian Signifikan

F hitung $>$ F tabel $=143,127>3,168$

Keterangan: Variabel Produktivitas Kerja

Sumber : data diolah 2020

Pada Tabel 4, nilai F hitung sebesar 143,127 jika dibadingkan dengan $\mathrm{F}$ tabel sebesar 3,168 , maka $\mathrm{F}$ hitung lebih besar dari $\mathrm{F}$ tabel $(143,127>3,168)$, artinya secara bersamasama kompetensi dan motivasi berpengaruh positif dan signifikan pada tingkat nyata $95 \%$ terhadap produktivitas kerja karyawan PT Astra International Daihatsu, Tbk Cibubur, atau dengan menggunakan $\mathrm{F}$ signifikan yaitu sebesar 0,000 lebih kecil dari tingkat kepercayaan 0.05 . Nilai koefisien determinasi $\left(\mathrm{R}^{2}\right)$ sebesar 0.841 , artinya variabel kompetensi dan motivasi memberikan kontribusi sebesar $84,1 \%$ kepada variabel produktivitas kerja karyawan PT Astra International Daihatsu, Tbk Cibubur, sedangkan sisanya sebesar 15,9\% disumbangkan faktor lain yang tidak dibahas dalam penelitian ini.

$$
\text { Persamaan Regresi } \mathrm{Y}=6,056+0,599\left(\mathrm{X}_{1}\right)+0,374\left(\mathrm{X}_{2}\right)
$$

Kompetensi dan motivasi berpengaruh positif dan signifikan terhadap produktivitas kerja karyawan PT Astra International Daihatsu, Tbk Cibubur pada tingkat nyata $99 \%$. Koefisien kompetensi sebesar 0,599 artinya jika ada peningkatan kompetensi satu kali, maka produktivitas kerja karyawan PT Astra International Daihatsu, Tbk Cibubur akan meningkat sebesar 0,599 kali atau sebaliknya dengan asumsi motivasi tidak berubah. Koefisien motivasi sebesar 0,374, artinya jika ada peningkatan motivasi satu kali, maka produktivitas kerja karyawan PT Astra International Daihatsu, Tbk Cibubur akan meningkat sebesar 0,374 kali atau sebaliknya, dengan asumsi kompetensi tidak berubah.

\section{Pembahasan}

\section{Pengaruh Kompetensi Terhadap Produktivitas Kerja Karyawan PT Astra International Daihatsu, Tbk Cibubur}

Dari hasil penelitian menunjukan bahwa adanya peningkatan kompetensi akan mendorong meningkatkan produktivitas kerja karyawan. Hal ini dikarenakan bahwa karyawan memiliki pengetahuan yang luas, sesuai dengan bidang yang dikerjakan, dapat menjelaskan produk dengan baik, memiliki ketrampilan yang dapat diandalkan, dapat dipercaya, ketrampila nyang relevan dengan tugas, taat terhadap peraturan yang berlaku, bertangung jawab atas beban kerja, dan selalu mengevaluasi hasil kerja yang diembannya. Hasil penelitian ini sejalan dengan hasil penelitian yang dilakukan Sudiastawan, et, al (2016) dan Kasifah, (2017) yang menyatakan bahwa kompetensi berpengaruh signifikan terhadap produktivitas kerja karyawan. Dengan demikian hipotesis pertama dapat diterima. 


\section{Pengaruh Motivasi Terhadap Produktivitas Kerja Karyawan PT Astra International Daihatsu, Tbk Cibubur}

Dari hasil penelitian menyatakan bahwa adanya peningkatan motivasi akan mendorong meningkatkan produktivitas kerja karyawan. Hal ini dikarenakan bahwa kebtuhan sandang dan pangan karyawan dapat terpenuhi, adanya jaminan dana pensiun, tersedianya fasilitas perlengkapan keselamatan kerja, pengakuan atas penghargaan atas kemampuan kerja, saling menghormati baik sesame rekan kerja maupun pimpinan, senang terhadap pekerjaan yang menarik dan menantang. Hasil penelitian ini sejalan dengan hasil penelitian yang dilakukan Safwan, et al (2014) dan Djuhara, (2014) yang menyatakan bahwa motivasi berpengaruh signifikan terhadap produktivitas kerja karyawan. Dengan demikian hipotesis kedua dapat diterima.

\section{Pengaruh Kompetensi dan Motivasi Terhadap Produktivitas Kerja Karyawan PT Astra International Daihatsu, Tbk Cibubur}

Berdasarkan hasil analisis diketahui bahwa kompetensi dan motivasi mendukung peningkatan produktivitas kerja karyawan PT Astra International Daihatsu, Tbk Cibubur. Hasil penelitian ini sama dengan hasil penelitian yang dilakukan Safwan, et al (2014)., Djuhara, (2014), Sudiastawan, et, al (2016) dan Kasifah, (2017) yang menyatakan bahwa analisis pengaruh kompetensi dan motivasi berpengaruh terhadap produktivitas kerja karyawan. Dengan demikian hipotesis ketiga dapat diterima.

\section{KESIMPULAN DAN SARAN}

\section{Kesimpulan}

Berdasarkan hasil pembahasan yang telah penulis sajikan pada bab sebelumnya dan melakukan praktik langsung pada perusahaan PT. Astra International Tbk Daihatsu, Tbk Cibubur, maka dapat ditarik kesimpulan sebagai berikut: 1). Kompetensi berpengaruh positif dan signifikan terhadap produktivitas kerja karyawan PT. Astra International Tbk Daihatsu, Tbk Cibubur. 2). Motivasi berpengaruh positif dan signifikan terhadap produktivitas kerja karyawan PT. Astra International Tbk Daihatsu, Tbk Cibubur. 3). Kompetensi dan motivasi secara bersama-sama berpengaruh positif dan signifikan terhadap produktivitas kerja karyawan PT. Astra International Tbk Daihatsu, Tbk Cibubur.

\section{Saran}

Setelah melakukan penelitian di PT. Astra International Daihatsu, Tbk Cibubur tentang kompetensi, motivasi dan produktivitas kerja karyawan, saran yang dapat saya berikan adalah sebagai berikut: 1). Bagi karyawan teknisi yang berhubungan langsung dengan kendaraan yang diperbaiki, kiranya terus dapat meningkatkan kompetensi yang dimilikinya, mengingat perkembangan kendaraan terus berkembang seiring dengan lajunya perkembangan teknologi. 2). Motivasi yang ada relatif sudah bagus, namun demikian perlu kiranya atasan selalu memberikan arahan-arahan yang berkaitan dengan pekerjaan yang dilakukan oleh bawahan, perhatian pimpinan atau atasan sangat mempengaruhi kerja bawahan agar mereka selalu semangat dalam bekerja. 3). Bagi peneliti selanjutnya disarankan untuk menambah variabel-variabel lain yang lebih beragam dalam membahas terkait produktivitas kerja karyawan, khsusunya dalam perusahaan yang bergerak dalam bidang otomatif. 


\section{DAFTAR PUSTAKA}

Adair, John. 2007. Decision Making \& Problem Solving Strategies. London: Kogan Page. Damayanti, Retno. 2005. Pengaruh Motivasi Kerja Karyawan terhadap Produktivitas Kerja Karyawan CV. Bening Natural Furniture di Semarang. Skripsi. Semarang: UNNES.

Dharma, Surya. 2010. Manajemen Kinerja. Edisi ketiga. Yogyakarta: Pustaka Pelajar.

Djuhara, Djadjun. 2014. "Pengaruh Motivasi Kerja, dan Kompetensi Terhadap Produktivitas Pada Karyawan Bagian Manajemen, Sirkulasi dan Iklan PT. Tribun Jabar Bandung". Jurnal Indonesia Membangun, Vol. 13, No. 1.

Flippo, Edwin B. 2002. Manajemen Personalia. Edisi VII Jilid II, Terjemahan Alponso S. Jakarta: Erlangga.

Handoko, T. Hani. 2012. Manajemen Personalia dan Sumber Daya Manusia. Yogyakarta: BPFE.

Hasibuan, Malayu S. P. 2013. Manajemen Sumber Daya Manusia. Jakarta: PT. Bumi Aksara.

Kasifah. 2017. "Pengaruh Kompetensi dan Motivasi Terhadap Produktivitas Kerja di Kantor Sekretariat Daerah Bagian Organisasi Tata Laksana Kabupaten Kutai Timur". E-Journal Pemerintah Integratif, 2017, 5(3): 320-330. ISSN:2337-8670 (online), ISSN 2337-8662 (print).

Mangkunegara, Anwar Prabu. 2015. Manajemen Sumber Daya Manusia Perusahaan. Bandung: Remaja Rosda Karya.

Maslow. Abraham H. 2003. Motivasi dan Kepribadian. Jakarta: Surya Grafindo.

Robbins, Stephen P. 2008. Perilaku Organisasi. Indonesia: Konsep Kontroversi, Aplikasi, Alih Bahasa: Hadayana Pujaatmaka. Jakarta: Prehalindu.

Ruky, Achmad S. 2003. Sistem Manajemen Kinerja. Jakarta: Gramedia Pustaka.

Safwan,. Nadirsyah dan Abdullah, Syukriy. 2014., "Pengaruh Kompetensi dan Motivasi Terhadap Kinerja Pengelolaan Keuangan Daerah Pada Pemerintah Daerah Kabupaten Pidie Jaya". Jurnal Akuntansi, Pascasarjana Univeritsas Syiah Kuala, pp. 133-139, ISSN 2302-0164.

Sedarmayanti. 2017. Manajemen Sumber Daya Manusia. Bandung: Refika Aditama.

Simanjuntak, Payaman J. 2011. Manajemen Evaluasi Kinerja. .Edisi 3. Jakarta: Fakultas UI.

Sinungan, Muchdarsyah. 2011. Produktivitas Apa dan Bagaimana. Jakarta: Bumi Aksara.

Sudiastawan, Kadek Yudha,. Bagia, I Wayan dan Suwendra, I Wayan. 2016. "Pengaruh Kompetensi Intelektual dan Motivasi Terhadap Produktivitas Kerja Karyawan". e-Journal Bisma Iniversitas Pendidikan Ganesha, Jurusan Manajemen Volume 4 Tahun 2016.

Sugiyono. 2016. Statikstika Untuk Penelitian. Bandung: Alfabeta.

Sutrisno, Edy. 2011. Manajemen Sumber Daya Manusia. Jakarta: Kencana.

Wibowo. 2011. Manajemen Kinerja. Jakarta: PT. Raja Grafindo Persada.

Winardi. 2007. Motivasi dan Pemotivasian Dalam Manajemen. Jakarta: Raja Grasindo Persada.

Zwell, Michael. 2010. Creating a Culture of Competence. New York: John Wiley \& Sons, Inc.

UU No. 13 Tahun 2003 Tentang Ketenagakerjaan. 